\title{
Jalur Sinyal dan Metabolisme Endocannabinoid: Tinjauan Pustaka
}

\author{
Hariyanto Raharjo, Loo ${ }^{1 *}$, Agusaputra, Harman ${ }^{2}$ \\ Departemen Biokimia, Fakultas Kedokteran, Universitas Wijaya Kusuma Surabaya ${ }^{1}$ \\ Departemen Patologi Anatomi, Fakultas Kedokteran, Universitas Wijaya Kusuma \\ Surabaya ${ }^{2}$ \\ *e-mail: loohariyantoraharjo835@gmail.com
}

\begin{abstract}
Abstrak
Efek biologis dari tumbuhan Cannabis Sativa dimediasi oleh dua buah reseptor dari kelompok G-protein coupled receptor; reseptor cannabinoid 1 (CB1R) dan 2 (CB2R). CB1R lebih banyak didapatkan pada Susunan Saraf Pusat dan berhubungan dengan pemberian terapi pada gangguan neuropsikologis dan penyakit neurodegeneratif. Selain itu endocannabinoid juga memodulasi jalur tranduksi sinyal dan menimbulkan efek pada jaringan perifer. Meskipun cannabionoid memiliki efek terapeutik, tetapi efek psikoaktifnya menyebabkan terbatasnya penggunaan endocannabionoid dalam praktek klinis. Namun kemajuan terkini dalam distribusi fisiologis dan pengaturan fungsional dari endocannabinoid memungkinkan adanya penelitian eksploitasi penggunaan endocannabionoid sebagai bahan terapeutik serta pengembangan obat baru dengan keunggulan farmakologis. Pada tinjauan pustaka ini, kami meninjau secara singkat tentang jalur metabolik dan jalur transduksi sinyal dari dua endocannabionoid utama; Anandamide (AEA) dan 2- arachidonoyglycerol (2-AG) yang mempunyai potensi terapeutik.
\end{abstract}

Kata Kunci: Endocannabinoid, Anandamide (AEA), arachidonoyglycerol (2-AG), Jalur metabolik, Jalur transduksi sinyal

\section{Signal Pathways and Endocannabinoid Metabolism: Literature Review}

\begin{abstract}
The biological effects of the Cannabis Sativa plant are mediated by two receptors from the Gprotein coupled receptor group; cannabinoid 1 (CB1R) and 2 (CB2R) receptors. CB1R is more commonly found in the Central Nervous System and associated with therapy in neuropsychological disorders and neurodegenerative diseases. In addition, endocannabinoids also modulate signal transduction pathways and cause effects on peripheral tissues. Although cannabinoids has a therapeutic effect, its psychoactive effects cause limited use of endocannabinoids in clinical practice. The recent advances in physiological distribution and functional regulation of endocannabinoid have enabled the exploitation of research to use endocannabinoids as a therapeutic agent and the development of new drugs with pharmacological superiority. In this literature review, we briefly review the metabolic pathways and signal transduction pathways of the two main endocannabinoids; Anandamide (AEA) and 2- arachidonoyglycerol (2-AG) which have therapeutic potential.
\end{abstract}

Keywords: Endocannabinoid, Anandamide (AEA), arachidonoyglycerol (2-AG), Metabolic pathway, Signal transduction pathway 


\section{PENDAHULUAN}

Sejak ribuan tahun yang lalu manusia sudah mengenal tumbuhan Cannabis Sativa, yang lebih dikenal sebagai marijuana, dipakai sebagai obat antinosisepsi, anti-inflamasi, anti konvulsan, anti-emetik serta dapat menimbulkan euforia dan relaksasi (Zou \& Kumar, 2018). Senyawa aktif dari Cannabis Sativa yang berhasil diisolasi dan diidentifikasi adalah $\Delta 9$-tetrahydrocannabinol (Gaoni \& Mechoulam, 1964), merupakan sebuah penemuan penting untuk mengetahui adanya sistem endocannabinoid yang memodulasi hampir setiap bagian otak dan berkontribusi terhadap hampir semua fungsi susunan saraf pusat (Maccarrone, 2010).

Sistem endocannabinoid merupakan suatu sistem neuromodulator yang tersebar luas di seluruh Susunan Saraf Pusat serta organ perifer (Hillard CJ, 2012). Komponen-komponen sistem endocannabinoid terdapat pada sepanjang sumbu hipothalamus-hipofise yang telah dibuktikan melalui beberapa penelitian. Sistem endocannabinoid terdiri dari reseptor spesifik, ligan endogen dan enzim untuk sintesis, degradasi dan transportasi ligan (Laurentiis, Araujo, \& Rettori, 2014).

Reseptor cannabinoid 1 (CB1R) merupakan suatu reseptor yang berpasangan dengan protein $\mathrm{G}$ yang paling banyak diekspresikan di otak dengan urutan sebagai berikut: Substantia Nigra, Globus Pallidus, Hippocampus, Korteks Serebral, Putamen, Nukleus Kaudatus, Serebellum, Amygdala (Glass M, 1997). Selain CB1R juga diekspresikan pada adiposit, hepatosit, dan jaringan muskuloskeletal (McPartland, Guy, \& Marzo, 2014). Sedangkan reseptor cannabinoid 2 (CB2R) pada prinsipnya berkaitan dengan sel-sel yang mengatur fungsi kekebalan tubuh, tetapi juga dapat diekspresikan pada Susunan Saraf Pusat (Onaivi ES, 2011).

Tinjauan pustaka ini kami susun untuk menerangkan tentang peranan sistem endocannabinoid di dalam tubuh manusia terutama yang berkaitan dengan proses-proses patologis. Harapan kami melalui tinjauan pustaka ini dapat menambah pengetahuan tentang sistem endocannabinoid.

\section{Sistem Endocannabinoid}

Ligan endogen yang disebut endocannabinoid, suatu mediator lipid yang merupakan derivat asam arakidonat, diisolasi dari otak dan jaringan perifer, serta memiliki efek mirip dengan $\Delta 9$ tetrahydrocannabinol (THC) pada berbagai proses biologis (Devane WA, 1992)

Endocannabinoid yang pertama kali berhasil diidentifikasi adalah Anandamide 
(AEA), suatu polyunsaturated fatty acid amide, yang dibentuk dari etanolamin yang terikat dengan asam lemak yang terdiri dari 20 atom karbon (Devane WA, 1992). Endocannabinoid kedua yang ditemukan adalah 2-arachidonoylglycerol (2-AG), merupakan suatu ester antara asam arakidonat dan gliserol yang diisolasi dari usus anjing (Sugiura T, 2002). Selain itu

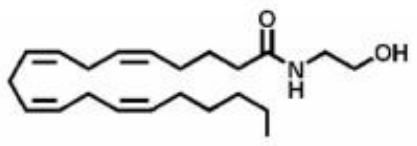

$\mathrm{N}$-Arachidonoylethanolamine (Anandamide, AEA)

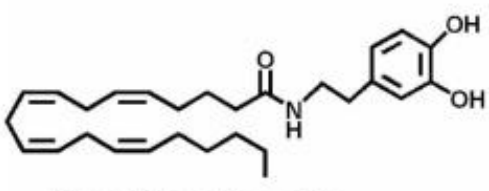

N-Arachidonoyldopamine (NADA)

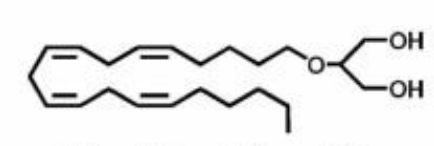

2-Arachidonoylglycerylether (Noladin ether)

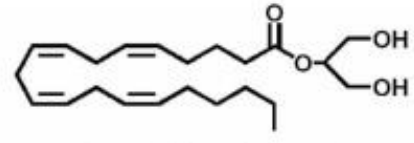

2-Arachidonoylglycerol (2-AG)

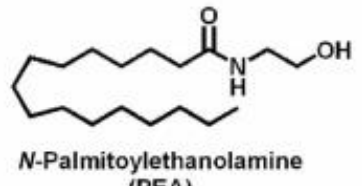

(PEA)

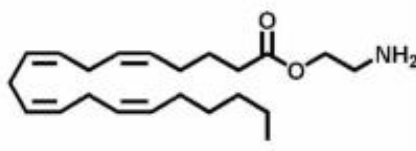

O-Arachidonoylethanolamine (Virodhamine)

Gambar 1. Struktur kimia dari Endocannabinoid yang aktif secara biologis dan senyawa mirip Endocannabinoid (Battista, Di Tommaso, Bari, \& Maccarrone, 2014)

Endocannabinoid dilepaskan "sesuai kebutuhan" dari prekursor membran fosfolipid (Muccioli, 2010), sedangkan Nacylphosphatidylethanolamine-specific phospholipase D (NAPE-PLD), saat ini dianggap sebagai enzim utama yang bertanggung jawab untuk produksi Anandamide (AEA) (Okamoto, 2009), sedangkan sintesis 2-arachidonoylglycerol (2-AG) dikatalisis oleh sn-1-diacylglycerol lipase (DAGL) (Ueda, 2011)
Sebagian besar penelitian tentang sistem endocannabinoid terfokus pada Anandamide (AEA) dan 2arachidonoylglycerol (2-AG), yang terdokumentasi dengan baik dan memiliki sifat yang berbeda (Di Marzo \& de Petrocellis, 2012). Anandamide (AEA) mempunyai afinitas tinggi dan menjadi agonis parsial bagi CB1R dan tidak aktif pada CB2R (Di Marzo \& de Petrocellis, 2012), sedangkan 2-arachidonoylglycerol (2-AG) bertindak sebagai agonis penuh 
Jalur Sinyal dan Metabolisme Endocannabinoid: Tinjauan Pustaka

Hariyanto Raharjo, Loo; Agusaputra, Harman

terhadap CB1R dan CB2R dengan afinitas sedang sampai rendah (Di Marzo \& de Petrocellis, 2012).

Mekanisme biosintesis dan degradasi Anandamide (AEA)

Mekanisme utama untuk biosintesis AEA melibatkan hidrolisis fosfolipid minor,
$\mathrm{N}$-acyl phosphatidylethanolamines (NAPE), yang disintesis oleh $\mathrm{N}$-acyl transferase (NAT) yang mengkatalisa perpindahan dan pembentukan ikatan amida antara gugus asil lemak pada posisi sn-1 dari donor fosfolipid dan etanolamin yang berasal dari Fosfatidiletanolamin (PE) (Parsons \& Hill, 2015).

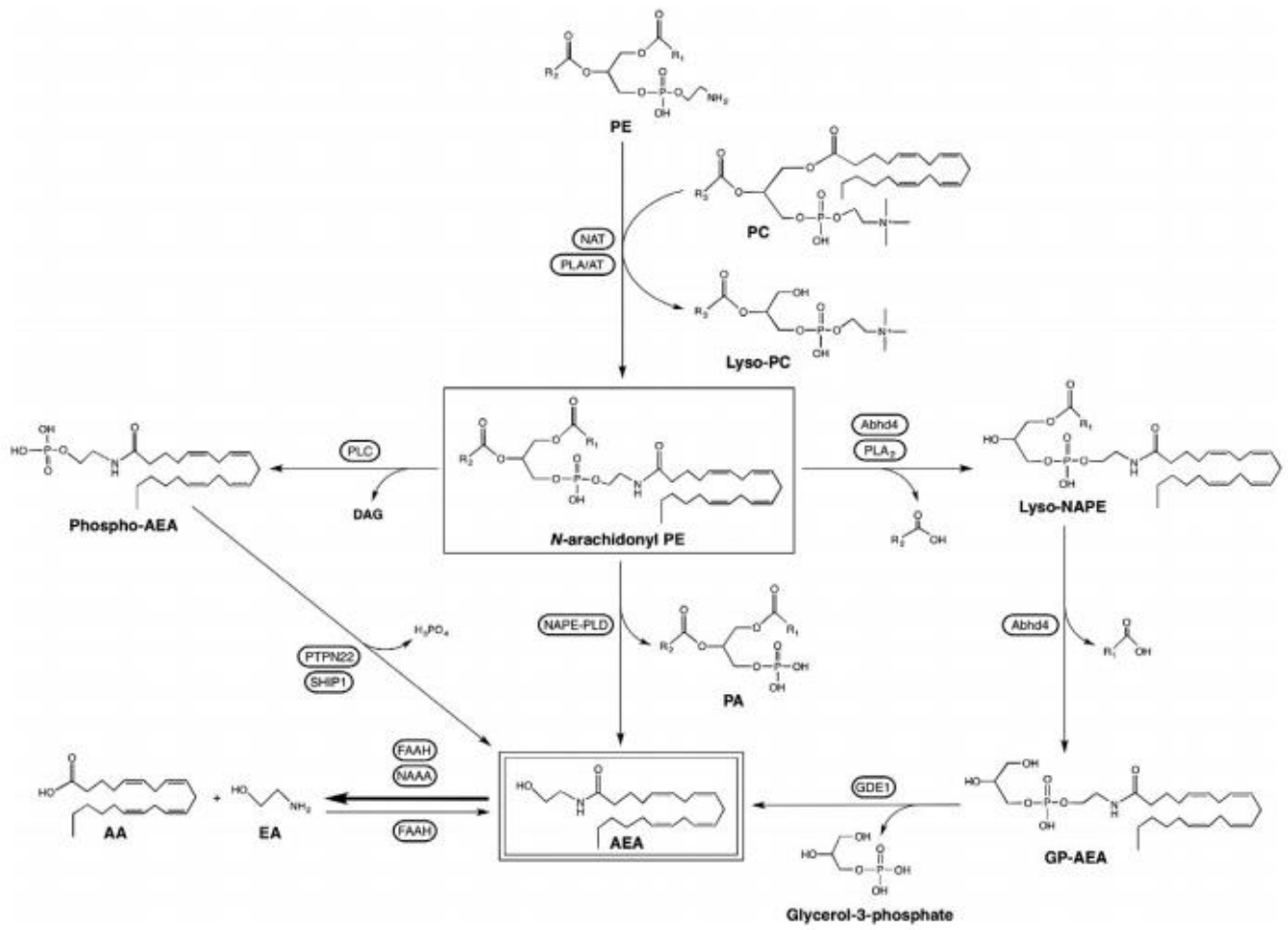

Gambar 2. Biosintesa dan Degradasi Anandamide (AEA) (Parsons \& Hill, 2015)

Aktivitas NAT dipengaruhi oleh kadar kalsium dan didapatkan pada membran sel otak (Cadas et al, 1996). Kelompok enzim lain yang berperan dalam pembentukan $\mathrm{N}$ acyl phosphatidylethanolamines (NAPE) adalah Fosfolipase A/ Asiltransferase (PLA/AT), yang diekspresikan dalam otak manusia, tikus, dan mencit (Golczak, 2012). PLA/AT mengkatalisa reaksi yang sama seperti NAT, tetapi tidak dipengaruhi kadar kalsium $\left(\mathrm{Ca}^{2+}\right)$ (Uyama, 2013). Ekspresi PLA/AT seluler yang berlebihan menghasilkan peningkatan konsentrasi NAPE secara signifikan (Uyama, 2013).

Selanjutnya NAPE mengalami perubahan menjadi Asam Fosfatidat (PA) dan NAE yang dikatalisa oleh $\mathrm{N}$-acyl phosphatidylethanolamine-specific phospholipase D (NAPE-PLD) (Schmid, 1990). N-acyl phosphatidylethanolamine- 
specific phospholipase D (NAPE-PLD) berhubungan dengan membran intraseluler (Okamoto Y. M., 2004). Dalam ventral pallidum, NAPE-PLD terdapat di terminal presinaptik yang berlawanan dengan terminal akson lain yang mengekspresikan CB1R, menunjukkan bahwa AEA dapat melakukan regulasi axoaxonal pensinyalan CB1R (Pickel, 2012). NAPE-PLD juga ditemukan didalam axon dan dendrit dari hipothalamus (Reguero, 2014).

NAPE dapat dideasilasi menjadi lysoNAPE dikatalisa oleh fosfolipase A2 dan alpha-beta hydrolase domain containing protein 4 (Abhd4) (Simon, 2006). Abhd4 yang diekspresikan dalam otak tikus dapat mengkatalisa deasilasi lyso-NAPE sehingga terbentuk glycerophospho-Nacylethanolamine (GP-NAE) (Laurentiis, Araujo, \& Rettori, 2014).

Selanjutnya GP-NAE mengalami hidrolisis menjadi gliserol 3-fosfat dan NAE yang dikatalisa oleh gliserofosfodiester fosfodiesterase 1 (GDE1), yang terdistribusi luas pada jaringan mamalia termasuk otak dan sumsum tulang belakang (Simon, 2008).

Jalur tambahan lainnya terjadi di dalam makrofag yang menghasilkan NAE dari NAPE yang melibatkan fosfolipase C, dimana NAPE dikonversi menjadi diasilgliserol (DAG) dan fosfo-NAE, yang kemudian mengalami defosforilasi oleh beberapa fosfatase, termasuk protein tirosin fosfatase, nonreceptor type 22 (PTPN22) dan Src homology 2-containing inositol phosphatase-1 (SHIP-1) (Liu, 2008)

Jalur sintesis AEA yang lain yang terjadi dalam jaringan mamalia adalah sintesis AEA dari Asam Arakidonat (AA) dan tidak melibatkan NAPE sebagai prekursor (Katayama, 1997). Pada jalur ini, NAEhydrolizing enzyme, Fatty Acid Amide Hydrolase (FAAH) berperan untuk memasangkan secara langsung Asam Arakidonat (AA) dengan etanolamin untuk membentuk AEA (Kurahashi, 1997).

Kadar Anandamide (AEA) dapat berubah sebagai respon terhadap rangsangan yang berbeda, tingkat perkembangan yang berbeda, kondisi patologis yang beragam, dan biasanya bertindak untuk memulihkan homeostasis dengan mengurangi eksitotoksisitas, inflamasi, kematian neuronal serta mengatur pelepasan hormon (Katona I., 2012).

\section{Mekanisme biosintesis dan degradasi 2- arachidonoylglycerol (2-AG)}

2-arachidonoylglycerol didapatkan pada jaringan otak dengan konsentrasi nanomolar (Buczynski, 2010). Mekanisme sintesa 2-AG melibatkan hidrolisis ikatan ester pada posisi sn-1 
Diasilgliserol (DAG) yang dikatalisa oleh diasilgliserol lipase (DAGL) (Bisogno, 2003). Pada mamalia terdapat dua buah isotipe DAGL, yaitu DAGL $\alpha$ dan DAGL $\beta$. DAGL $\alpha$ memiliki terminal-C yang besar. Kedua isoenzim tersebut diekspresikan di otak. Namun DAGLa hadir dengan kepadatan tinggi pada daerah perisinaptik dari dendrit di banyak daerah otak (Matyas, 2008).

Ada beberapa bukti bahwa PKA dan Protein Kinase C (PKC) dapat menstimulasi aktivitas DAGL (Vellani, 2008). DAGL $\alpha$ mengalami fosforilasi pada dua buah serin di daerah terminal-C oleh calcium/ calmodulin-dependent kinase II yang mengakibatkan aktivitas DAGL $\alpha$ terhambat dan menjelaskan adanya peranan $\mathrm{Ca}^{2+}$ yang dapat menimbulkan feedback inhibition pada sintesis 2-AG (Shonesy, 2013). Analisa proteomik menunjukkan bahwa kedua isoform DAGL dapat mengalami palmitoilasi (Yang, 2010). Aktivitas katalitik DAGL $\alpha$ dan DAGL $\beta$ tidak berbeda (Bisogno, 2003) sehingga domain c-terminal pada DAGLa tidak penting untuk aktivitas enzimatik.

Domain c-terminal pada DAGL $\alpha$ mengandung motif konsensus untuk mengikat protein Homer (Jung, 2007). Meskipun interaksi antara DAGL $\alpha$ dan protein Homer ditemukan penting untuk hubungan DAGLa dengan membran plasma dalam cell line, interaksi ini tidak diperlukan untuk sintesis 2-AG (Jung, 2007). Beberapa penelitian telah menunjukkan bahwa protein Homer diperlukan untuk perubahan transmisi sinaptik yang dimediasi endocannabinoid, menunjukkan bahwa lokasi DAGL $\alpha$ dalam sel diatur oleh protein Homer dan proses ini diperlukan untuk aktivasi 2-AG-mediated signaling yang efisien (Roloff, 2010).

Tetrahydrolipstatin (THL; orlistat) adalah inhibitor dengan afinitas tinggi terhadap DAGL pada konsentrasi yang tidak menimbulkan efek pada monoacylglycerol lipase (MAGL) atau NAPE-PLD (Bisogno T. C., 2006) dan inhibitor poten terhadap 2-AG in vitro (Hashimotodani, 2008). Tetrahydrolipstatin (THL; orlistat) juga merupakan inhibitor broad range terhadap pankreatik dan gastrik lipase serta bersifat ireversibel (Guerciolini, 1997). RHC 80267 adalah inhibitor DAGL yang mempengaruhi efek pada CB1R yang dimediasi oleh pemberian 2-AG secara eksogen, menunjukkan efek langsung pada CB1R signaling (Hashimotodani, 2008). OMDM-188 (nama kimiawi: N-Formyl---isoleucine-(1S)-1[[(2S,3S)-3-hexyl-4-oxo-2-

oxetanyl]methyl]dodecyl ester) adalah Tetrahydrolipstatin (THL; orlistat) analog (Ortar, 2008), juga merupakan inhibitor DAGL in vitro yang poten dan selektif (Hashimotodani Y. ,2013). LEI-105 (nama 
kimiawi: 6-Phenyl-1-(6-(p-tolyl)oxazolo[4,5-

b]pyridin-2-yl)hexan-1-one) adalah inhibitor reversibel bagi DAGL $\alpha$ and DAGL $\beta$, tanpa menimbulkan efek pada enzim katabolik 2-AG atau FAAH, dan menurunkan kadar 2-AG tetapi tidak menurunkan kadar AEA pada sel-sel Neuro 2A (Baggelaar, 2015).
Kelompok enzim fosfolipase C (PLC), terutama PLC $\beta$ and PLCY, bekerja pada fosfatidilinositol 4,5-bisfosfat $\left(\mathrm{PIP}_{2}\right)$ untuk membentuk diasilgliserol (DAG) dan Inositol Trifosfat $\left(\mathrm{IP}_{3}\right)$. Jalur ini menghubungkan regulasi sintesa 2-AG dengan $G$ protein-coupled receptors (GPCRs), karena protein Gaq mengaktifkan PLC $\quad$ (Jung, 2007).
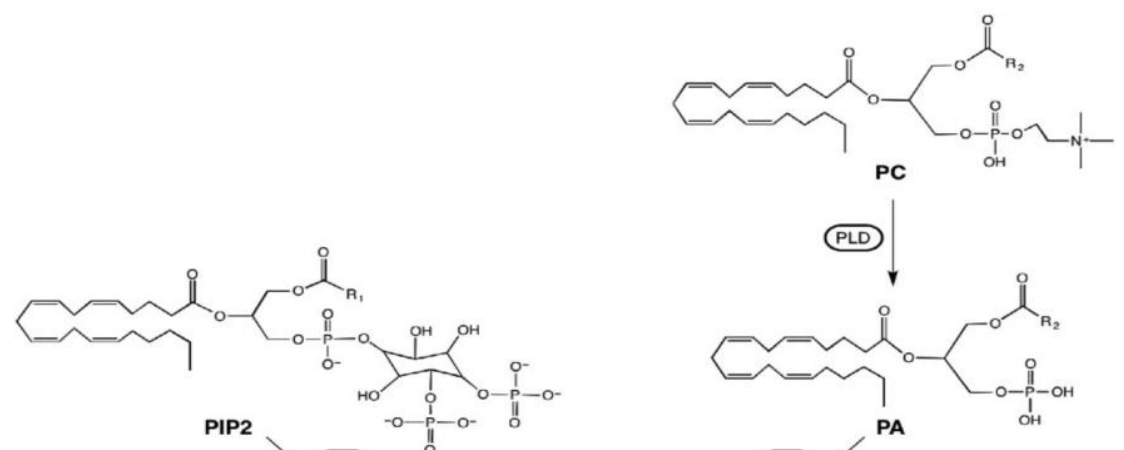

PIP

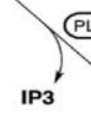

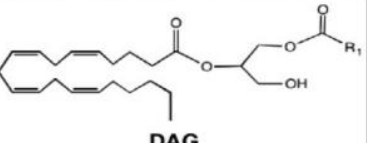<smiles>c1ccccc1</smiles>

$\downarrow$

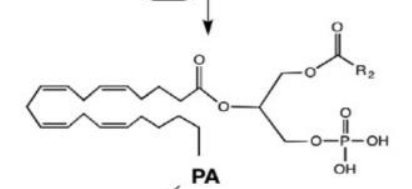
PA

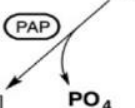

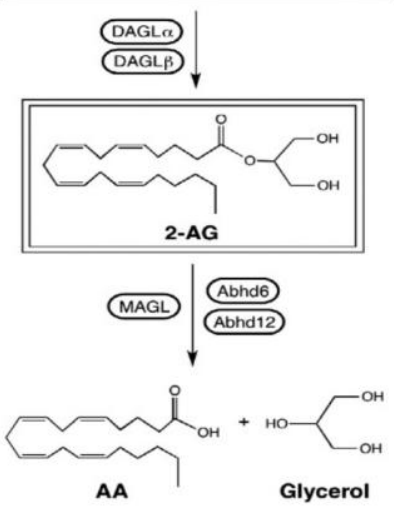

Gambar 3. Biosintesa dan Degradasi 2-arachidonoylglycerol (2-AG) (Parsons \& Hill, 2015)

Seperti halnya PLC $\beta$, isoform PLC $\gamma$ bekerja pada fosfatidilinositol 4,5-bisfosfat (PIP2) untuk membentuk diasilgliserol (DAG), tetapi mengikuti jalur tirosin kinase, growth factor receptor, menunjukkan bahwa sintesa 2-AG dapat diregulasi oleh kelompok enzim ini (Zhao, 2014). Kombinasi antara studi inhibitor dan analisis zat intermediate menunjukkan bahwa kalsium dapat meningkatkan produksi DAG melalui jalur dua enzim: Fosfolipase D (PLD) menghasilkan asam 
fosfatidat (PA), kemudian diikuti proses defosforilasi asam fosfatidat (PA) yang dikatalisa PA fosfatase (Parsons \& Hill, 2015).

2-AG dikatabolisme dengan menghidrolisis ikatan ester antara Asam Arakidonat dan gliserol oleh beberapa enzim. Monoasilgliserol Lipase (MAGL) bertanggungjawab atas lebih dari $85 \%$ hidrolisis 2-AG oleh otak (Blankman, 2007) dan merupakan mekanisme yang dominan untuk inaktivasi 2-AG dalam peranannya sebagai CB1R agonis pada neuron (Murataeva, 2014). MAGL menghidrolisis 1(3)- dan 2- monoasilgliserol dengan sedikit kemampuan untuk menghidrolisis triasilgliserol atau DAG. MAGL tersebar di seluruh tubuh termasuk otak (Murataeva, 2014).

Aktivitas MAGL sitosolik ditemukan berkurang 50\% pada adiposit dari tikus yang puasa, sedangkan aktivitas MAGL tidak berubah. Keadaan stress kronis secara selektif mengurangi protein MAGL yang terdeteksi dalam membran tetapi tidak dalam sitosol dari amigdala basolateral (Sumislawski, 2011). Beberapa penelitian menunjukkan penurunan ekspresi mRNA MAGL dalam jaringan yang mengalami inflamasi (Mai, 2015). Peningkatan neuregulin-1 yang berkelanjutan menyebabkan peningkatan ekspresi MAGL pada irisan hippocampal, kemungkinan melalui aktivasi reseptor ErbB4, suatu reseptor tirosin kinase yang merupakan anggota reseptor epidermal growth factor (Du, 2013). Faktor transkripsi dan tumor suppressor Prdm5 (Protein Domain Zinc Finger Protein 5) adalah reppressor ekspresi MAGL dan menyebabkan hilangnya sinergisitas MAGL yang mengaktivasi Wnt signaling pathway untuk meningkatkan ekspresi MAGL dan untuk meningkatkan pembentukan adenoma (Galli, 2014).

\section{Endocannabinoid-Mediated Signaling}

Konsentrasi basal 2-AG sekitar 1000 kali lebih tinggi daripada AEA in the brain. Enzim yang mengkatalisis biosintesis Anandamide (AEA) dari prekursornya bersifat sensitif terhadap peningkatan kadar $\mathrm{Ca}^{2+}$ intraseluler akibat adanya $\mathrm{Ca}^{2+}$ yang masuk (seperti setelah depolarisasi neuron) (van der Stelt $M, 2005$ ) atau mobilisasi dari tempat penyimpan intraseluler (seperti stimulasi pasangan reseptor metabotropik oleh protein $\mathrm{Gq} / 11$ ) atau kombinasi dari keduanya pada saat aktivitas susunan saraf pusat meningkat (Jung KM, 2005). Pada kebanyakan kasus, endocannabinoid-mediated retrograde signaling dimulai dengan produksi 2-AG, sebagai respon terhadap peningkatan kadar $\mathrm{Ca}^{2+}$ intraseluler dan aktivasi pasangan reseptor dengan protein $\mathrm{Gq} / 11$ 
(Kano, Ohno-Shosaku, Hashimotodani, Uchigashima, \& Watanabe, 2009). Kemudian 2-AG dilepaskan kedalam dan melintasi ruang ekstraseluler, melalui mekanisme yang belum sepenuhnya diketahui, dan tiba di terminal presipnatik dimana akan berikatan dengan CB1R.

Aktivasi CB1R menyebabkan penekanan pelepasan neurotransmitter melalui dua cara, yaitu: pertama, menghambat voltage-gated $\mathrm{Ca}^{2+}$ channels, dimana menurunkan influks $\mathrm{Ca}^{2+}$ presinaptik; Kedua, menghambat adenilat siklase (AC) dan jalur CAMP/PKA, yang terlibat dalam Long Term Depression (LTD) (Castillo, Younts, Chavez, \& Hashimotodani, 2012). Penghentian proses ini dengan degradasi 2-AG oleh MAGL, yang diekspresikan secara selektif pada terminal sinaptik dan sel-sel glial (Murataeva, Straiker, \& Mackie, 2014).

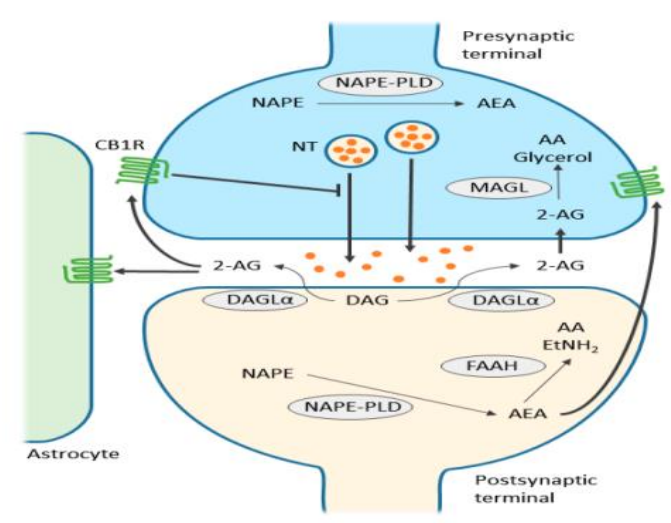

Gambar 4. endocannabinoid-mediated retrograde signaling (Battista, Di Tommaso, Bari, \& Maccarrone, 2014)

CB1R yang diaktifkan kemudian akan menghambat pelepasan neurotransmitter (NT) melalui penekanan masuknya kalsium. 2-AG adalah juga mampu mengaktifkan CB1R yang terletak di astrosit, yang mengarah ke pelepasan glutamat (Marinelli, Pacioni, Cannich, Marsicano, \& Bacci, 2009). Ekstra 2-AG yang terdapat pada celah sinaptik diambil ke terminal presinaptik, melalui mekanisme yang belum jelas, dan terdegradasi menjadi asam arakidonat (AA) dan gliserol oleh monoacylglycerol lipase (MAGL) (Stella, 2009).

Disamping itu, AEA, disintesis dalam terminal postsinaptik, mengaktifkan CB1R intraseluler dan target non-CBR lainnya, seperti Transient Receptor Potential Cation channel Subfamily $V$ member 1 (TRPV1) (Di Marzo \& de Petrocellis, Why do cannabinoid receptors have more than one endogenous ligand?, 2012). Meskipun pensinyalan retrograde endocannabinoid terutama dimediasi oleh 2-AG, AEA dapat 
juga mengaktifkan CB1R presinaptik

(Puente, et al., 2011)

Fatty acid amide hydrolase (FAAH) yang terutama ditemukan di terminal post sinaptik, biasa disebut FAAH-1 like anandamide transporter (FLAT) (Fu, 2011), bertanggung jawab untuk proses degradasi AEA menjadi Asam Arakidonat dan etanolamin (EtNH2) (Schlosburg, et al., 2010). Meskipun NAPE-PLD diekspresikan pada terminal presinaptik dibeberapa daerah otak, belum jelas apakah AEA bertanggung jawab atas anterograde endocannabinoid signalling (Marinelli, et al., 2008).

\section{Reseptor Endocannabinoid}

Ada dua buah reseptor endocannabinoid yang telah diidentifikasi, yaitu: reseptor $\mathrm{CB} 1$ (CB1R) yang dikloning pada tahun 1990, dan reseptor CB2 (CB2R) yang dikloning pada tahun 1993, dimana keduanya merupakan anggota dari $G$ Protein coupled receptor (Di Marzo \& de Petrocellis,2012).

CB1R pertama kali ditemukan di otak. Kemudian dengan menggunakan autoradiografi, hibridisasi in situ, dan imunohistokimia, terbukti bahwa CB1R merupakan reseptor protein dari keluarga $G$ protein-coupled receptors (GPCR) yang paling banyak terdapat di otak (Kano, Ohno-Shosaku, Hashimotodani, 2009).
Daerah di otak yang mempunyai ekspresi CB1R tertinggi adalah bulbus olfactorius, hippocampus, basal ganglia, dan serebellum (Mackie, 2005). Ekspresi CB1R yang sedang ditemukan di korteks serebral, septum, amigdala, hipothalamus, bagian dari batang otak, dan medulla spinalis dorsal (Mackie, 2005). Sedangkan thalamus dan medulla spinalis ventral memiliki ekspresi CB1R yang rendah (Mackie, 2005).

CB1R juga banyak diekspresikan pada sistem saraf perifer, terutama pada terminal saraf simpatis (Maccarrone, et al., 2015). Selain itu CB1R juga didapatkan pada ganglion trigeminal, ganglion dorsalis, dan ujung saraf dermal dari neuron sensorik primer, yang mengatur nosisepsi dari serabut saraf aferen (Tam, et al., 2008).

Di dalam Traktus Gastrointestinal, CB1R banyak didapatkan pada sistem saraf enterik dan sel-sel non neuronal di mukosa usus, termasuk sel enteroendokrin, sel imun, dan enterosit (Izzo \& Sharkey, 2010). CB1R memodulasi mobilitas traktus gastrointestinal, sekresi asam lambung, cairan, neurotransmitter dan hormon, serta permeabilitas epitel usus, yaitu melalui jalur neuronal dan non-neuronal. Oleh karena itu CB1R dapat mengendalikan nafsu makan dari hippothalamus, serta mengatur keseimbangan energi dan asupan makanan dari traktus gastrointestinal (Miller \& Devi, 2011). 
Aktivasi pada CB1R menghasilkan inhibisi terhadap adenilat siklase pada sebagian besar jaringan dan sel melalui aktivasi Gai-mediated signaling (Howlett, 1985), yang menimbulkan inhibisi pembukaan Voltage-dependent Calcium Channels (VDCCs) melalui pelepasan subunit $\beta \gamma$ (Mackie K. \&., 1992).

Aktivasi CB1R bergabung dengan aktivasi kinase yang diaktivasi oleh p42/p44 and p38 mitogen dan Jun $\mathrm{N}$ terminal kinase melalui berbagai mekanisme pensinyalan, termasuk oleh protein G (Turu, 2010) dan $\beta$-arrestin (Ahn, 2012). Aktivasi CB1R juga berkaitan dengan aktivasi fosfolipase C (PLC) (Lograno, 2004) dan Akt signaling (Gomez, 2011) di beberapa sel, dimana melalui jalur ini, aktivasi CB1R dapat mempengaruhi kadar kalsium intraseluler, aktivitas protein kinase, dan kaskade signaling lainnya yang mengatur pertumbuhan dan differensiasi sel.

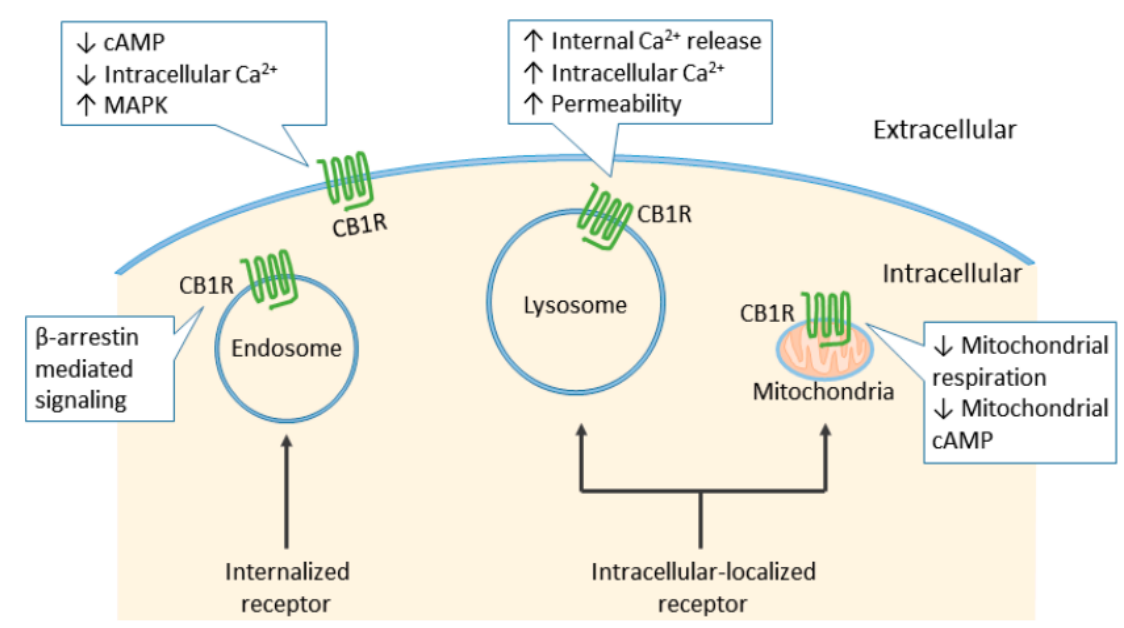

Gambar 5. Lokasi CB1R subseluler (Kumar, 2018)

Aktivasi CB1R juga diketahui menghambat pelepasan GABA dan glutamat dari terminal presinaptik sehingga CB1R dapat memodulasi neurotransmisi (Gerdeman \& Lovinger, 2001). Mekanisme ini yang mendasari terjadinya neuroprotektif yang dimediasi oleh CB1R terhadap proses eksitoksisitas, termasuk epilepsi dan penyakit neurodegeneratif (Marsicano, et al., 2003).
Selain itu efek neuroprotektif dari CB1R juga menyebabkan inhibisi sintesa Nitrit Oksida (NO), Reduksi terhadap mobilisasi zinc, peningkatan ekspresi Brain Derived Neurotrophic Factor (BDNF) (SanchezBlazquez, Rodriguez-Munoz, VicenteSanchez, et.al., 2013).

Aktivasi CB1R juga terlibat dalam kondisi fisiologis dan patologis di Susunan Saraf Tepi dan jaringan perifer, seperti 
nyeri, metabolisme energi, fungsi kardiovaskuler dan reproduksi, inflamasi, glaukoma, kanker, dan gangguan hepar dan muskuloskeletal (Maccarrone, et al., 2015). Ekspresi CB1R sangat fluktuatif pada banyak kondisi patologis, menunjukkan peran penting pada aktivitas biologis dengan spektrum yang luas (Miller \& Devi, 2011). Selain itu pemberian agonis CB1R menimbulkan efek bifasik pada beberapa kondisi (Di Marzo, 2008). Fakta-fakta tersebut menunjukkan pentingnya untuk memahami dan memanipulasi sistem endocannabinoid dengan cara khusus.

AEA dan 2-AG dapat mengikat reseptor cannabionoid CB2 (CB2R) yang merupakan $G$ protein-coupled receptors (Munro, 1193). CB2R diekspresikan dalam sirkulasi sel imun (Bouaboula, 2005), limfa (Carlisle, 2002), dan populasi makrofag dalam jaringan termasuk sel mikroglial. CB2R juga diekspresikan pada beberapa populasi neuron, meskipun kadar ekspresinya lebih rendah daripada CB1R (Van Sickle, 2005).

Anandamide (AEA) adalah agonis reseptor vanilloid tipe 1 , juga disebut TRPV1 (Kim, 2007). TRPV1 adalah saluran kation non-selektif yang diekspresikan secara luas di Susunan Saraf Pusat (Saghatelian, 2006). AEA intraseluler menginduksi pembukaan saluran, dan fungsi ini berkontribusi terhadap banyak efek AEA pada reseptor non-CB1. AEA dan NAE lainnya adalah agonis Peroxisome proliferator-activated receptor (PPAR), khususnya PPAR $\alpha$ (Lo Verme, 2005).

\section{KESIMPULAN}

Senyawa endocannabinoid merupakan suatu target yang menarik untuk pengembangan senyawa selektif dan spesifik yang dapat memodulasi proses patofisiologis pada tubuh manusia. Pemahaman yang lebih dalam dan lebih rinci tentang protein yang terlibat dalam metabolisme endocannabinoid dan jalur transduksi sinyal dapat membantu untuk merancang senyawa yang dapat memperpanjang aktivitas endocannabinoid sesuai dengan waktu dan lokasi, tidak termasuk efek psikotropik yang tidak diinginkan, serta untuk pengembangan tikus transgenik yang memungkinkan untuk terapi inovatif pada berbagai kondisi patologis.

\section{DAFTAR PUSTAKA}

Ahn KH, 2012. Allosteric modulator ORG27569 induces CB1 cannabinoid receptor high affinity agonist binding state, receptor internalization, and $\mathrm{Gi}$ proteinindependent ERK1/2 kinase activation. The Journal of 


\begin{abstract}
Biological Chemistry. (287): 12070-12082.

Baggelaar MP, 2015. Highly selective, reversible inhibitor identified by comparative chemoproteomics modulates diacylglycerol lipase activity in neurons. Journal of the American Chemical Society. (137): 322-338.

Battista N, Di Tommaso M, Bari M, \& Maccarrone M, 2014. The endocannabinoid system: an overview. BEHAVIORAL NEUROSCIENCE.1-8.
\end{abstract}

Bisogno TC, 2006. Development of the first potent and specific inhibitors of endocannabinoid biosynthesis. Biochimica et Biophysica Acta. (1761): 205-212.

Bisogno TH, 2003. Cloning of the first sn1DAG lipases points to the spatial and temporal regulation of endocannabinoid signaling in the brain. The Journal of Cell Biology. (163): 463-468.

Blankman JL, 2007. A comprehensive profile of brain enzymes that hydrolyze the endocannabinoid 2-arachidonoylglycerol. Chemistry \& Biology.(14): 13471356.

Bouaboula MH, 2005. Anandamide induced PPARgamma transcriptional
activation and
3T3-L1
preadipocyte differentiation.
European Journal of
Pharmacology. (517): 174-181.

Buczynski MW, 2010. Quantification of brain endocannabinoid levels:Methods, interpretations and pitfalls. British Journal of Pharmacology. (160): 423-442.

Cadas HG, 1996. Biosynthesis of an endogenous cannabinoid precursor in neurons and its control by calcium and cAMP. Journal of Neuroscience. 12(16): 3934-3942.

Carlisle SJC, 2002. Differential expression of the CB2 cannabinoid receptor by rodent macrophages and macrophage-like cells in relation to cell activation. International Immunopharmacology.(2): 69-82.

Castillo P, Younts T, Chavez A, \& Hashimotodani $\quad$ Y, 2012. Endocannabinoid signaling and synaptic function. Neuron.(76): 70-81.

Devane WAHL, 1992. Isolation and structure of a brain constituent that binds to the cannabinoid receptor. Science.(258): 19461949.

Di Marzo V, 2008. Targeting the endocannabinoid system: To 
enhance or reduce? Nat. Rev. Drug Discov.(7): 438-455.

Di Marzo V, \& de Petrocellis L. 2012. Why do cannabinoid receptors have more than one endogenous ligand? Philosophical Transactions of the Royal Society B: Biological Sciences.(367): 32163228.

Du HK, 2013. Neuregulin-1 impairs the long-term depression of hippocampal inhibitory synapses by facilitating the degradation of endocannabinoid 2-AG. The Journal of Neuroscience.(33): 15022-15031.

ES O, 2011. Commentary: functional neuronal CB2 cannabinoid receptors in the CNS. Current Neuropharmacology.(9): 205-208.

Fu JB, 2011. A catalytically silent FAAH-1 variant drives anandamide transport in neurons. Nat. Neurosci.(15): 64-69.

Galli GG, 2014. Prdm5 suppresses Apc(Min)-driven intestinal adenomas and regulates monoacylglycerol lipase expression. Oncogene.(33): 3342-3350.

Gaoni Y, \& Mechoulam R, 1964. Isolation, structure, and partial synthesis of an active constituent of hashish.
Journal of the American Chemical Society.(86): 1646-1647.

Gerdeman G, \& Lovinger D, 2001. CB1 cannabinoid receptor inhibits synaptic release of glutamate in rat dorsolateral striatum. J. Neurophysiol: 468-471.

Glass MDM, 1997. Cannabinoid receptors in the human brain: a detailed anatomical and quantitative autoradiographic study in the fetal, neonatal and adult human brain. Neuroscience.(77): 299318.

Golczak MK, 2012. Structural basis for the acyltransferase activity of lecithin:Retinol acyltransferaselike proteins. The Journal of Biological Chemistry.(287): 23790-23807.

Gomez, O. S.-R.-C.-H.-H. (2011). Cannabinoid receptor agonists modulate oligodendrocyte differentiation by activating $\mathrm{PI3K} /$ Akt and the mammalian target of rapamycin (mTOR) pathways. British Journal of Pharmacology(163), 1520-1532.

Guerciolini R, 1997. Mode of action of orlistat. International Journal of Obesity and Related Metabolic Disorders.(21): S12-S23. 
Hashimotodani 2008.

Pharmacological evidence for the involvement of diacylglycerol lipase in depolarization induced endocanabinoid release. Neuropharmacology.(54): 58-67.

Hashimotodani YOS, 2013. Acute inhibition

of diacylglycerol lipase blocks endocannabinoid-mediated retrograde signalling: Evidence for on-demand biosynthesis of 2arachidonoylglycerol. The Journal of Physiology.(591): 4765-4776.

Hillard CJ, W. K. (2012). Contributions of the endocannabinoid signaling to psychiatric disorders in humans: genetic and biochemical evidence. Neuroscience(204), 207-229.

Howlett AC, 1985. Cannabinoid inhibition of adenylate cyclase. Biochemistry of the response in neuroblastoma cell membranes. Molecular Pharmacology.(27): 429-436.

Izzo A,\& Sharkey K, 2010. Cannabinoids and the gut: New developments and emerging concepts. Pharmacol.Ther.(126): 21-38.

Jung KMMR, 2005. Stimulation of endocannabinoid formation in brain slice cultures through activation of group I metabotropic glutamate receptors. Mol Pharmacol.(68): 1196-1202.

Jung KM, 2007. A key role for diacylglycerol lipase-\{alpha\} in metabotropic glutamate receptor-dependent endocannabinoid mobilization. Molecular Pharmacology.(72): 612-621.

Kano M, Ohno-Shosaku T, Hashimotodani Y, Uchigashima $M$, \& Watanabe $M$, 2009. Endocannabinoid-mediated control of synaptic transmission. Physiol. Rev.(89): 309-380.

Katayama KU, 1997. Distribution of anandamide amidohydrolase in rat tissues with special reference to small intestine. Biochimica et Biophysica Act.(1347): 212-218.

Katona IFT, 2012. Multiple functions of endocannabinoid signaling in the brain. Annu Rev Neurosci.(35): 529-558.

Kim SR, 2007. Roles of transient receptor potential vanilloid subtype 1 and cannabinoid type 1 receptors in the brain: Neuroprotection versus neurotoxicity. Molecular Neurobiology.(35): 245-254.

Kumar SZ, 2018. Cannabinoid Receptors and the Endocannabinoid System: Signaling and Function in the Central Nervous System. 
International Journal of

Molecular Sciences: 2-23.

Kurahashi YU, 1997. Reversible hydrolysis and synthesis of anandamide demonstrated by recombinant rat fatty-acid amide hydrolase. Biochemical and Biophysical Research Communications. (273): 512-515.

Laurentiis AD, Araujo H, \& Rettori V, (2014). Role of the Endocannabinoid System in the Neuroendocrine Responses to Inflammation. Current Pharmaceutical Design.(20): 1-10.

Liu JWW, 2008. Multiple pathways involved in the biosynthesis of anandamide.

Neuropharmacology.(54): 1-7.

Lo Verme, J. F. (2005). The nuclear receptor peroxisome proliferatoractivated receptor-alpha mediates the anti-inflammatory actions of palmitoylethanolamide. Molecular Pharmacology(67), 1519.

Lograno, M. D. (2004). Cannabinoid agonists induce contractile responses through Gi/odependent activation of phospholipase $\mathrm{C}$ in the bovine ciliary muscle. European Journal of Pharmacology,(494), 55-62.
Maccarrone MD, 2010. Intracellular trafficking of anandamide: new concepts for signaling. Trends Biochemical Sciences.(35): 601608.

Maccarrone M, Bab R, Biro T, Cabral G, Dey S, di Marzo, V, 2015. Endocannabinoid signaling at the periphery: 50 years after THC. Trends Pharmacol. Sci.(36): 277296.

Mackie K, 1992. Cannabinoids inhibit Ntype calcium channels in neuroblastoma-glioma cells. Proceedings of the National Academy of Sciences of the United States of America.(89): 3825-3829.

Mackie K, 2005. Distribution of cannabinoid receptors in the central and peripheral nervous system. Handb. Exp.Pharmacol: 299-325

Mai PY, 2015. Endocannabinoid system contributes to liver injury and inflammation by activation of bone marrow-derived monocytes/macrophages in a CB1-dependent manner. Journal of Immunology.(195): 3390-3401. Marinelli S, Pacioni S, Bisogno T, di Marzo V, Prince D, Huguenard J, \& Bacci A, 2008. The endocannabinoid 2- 
arachidonoylglycerol is responsible for the slow selfinhibition in neocortical interneurons. J. Neurosci. (28):13532-13541.

Marinelli S, Pacioni S, Cannich A, Marsicano G, \& Bacci A, 2009. Selfmodulation of neocortical pyramidalneurons by endocannabinoids. Nat. Neurosci.(12): 1488-1490.

Marsicano G, Goodenough S, Monory K, Hermann H, Eder M, Cannich A, 2003. CB1 cannabinoid receptors and on-demand defense against excitotoxicity. Science. (302): 8488.

Matyas FU, 2008. Identification of the sites of 2-arachidonoylglycerol synthesis and action imply retrograde endocannabinoid signaling at both GABAergic and glutamatergic synapses in the ventral tegmental area. Neuropharmacology.(54): 95-107. McPartland J, Guy G, \& Marzo V, 2014. Care and Feeding of the Endocannabinoid System: A Systematic Review of Potential Clinical Interventions that Upregulate the Endocannabinoid System. PLoS ONE. 3(9): 1-22.
Miller L, \& Devi L, 2011. The highs and lows of cannabinoid receptor expression in disease: Mechanisms and their therapeutic implications. Pharmacol. Rev.(63): 461-470.

Muccioli G, 2010. Endocannabinoid biosynthesis and inactivation, from simple to complex. . Drug Discov. Today: 474-483.

Munro STS, 1193. Molecular characterization of a peripheral receptor for cannabinoids. Nature.(365): 61-65.

Murataeva N, Straiker A, \& Mackie K, (2014). Parsing the players: 2arachidonoylglycerol synthesis and degradation in the CNS. Br. J. Pharmacol.(171): 1379-1391.

Okamoto YM, 2004. Molecular characterization of a phospholipase D generating anandamide and its congeners. The Journal of Biological Chemistry.(279): 5298-5305.

Okamoto YT, 2009. Enzymatic formation of anandamide. Vitam. Horm.:1-24.

Ortar GB, 2008. Tetrahydrolipstatin analogues as modulators of endocannabinoid 2arachidonoylglycerol metabolism. Journal of Medicinal Chemistry.(51): 6970-6979. 
Parsons L, \& Hill M, 2015. INTERNATIONAL REVIEW OF NEUROBIOLOGY: Endocannabinoids (125 ed.) London, United Kingdom: Elsevier Inc.

Pickel VM, 2012. Cannabinoid-1 receptors in the mouse ventral pallidum are targeted to axonal profiles expressing functionally opposed opioid peptides and contacting $\mathrm{N}$ acylphosphatidylethanolaminehydrolyzing phospholipase D terminals. Neuroscience: 10-21.

Puente N, Cui Y, Lassalle O, Lafourcade M, Georges F, Venance L, Manzoni O, 2011. Polymodal activation of the endocannabinoid system in the extended amygdala. Nat. Neurosci.(14): 1542-1567.

Reguero LEUL, 2014. Subcellular localization of NAPE-PLD and DAGL-alpha in the ventromedial nucleus of the hypothalamus by a preembedding immunogold method. Histochemistry and Cell Biology.(141): $\quad$ 543-550. doi:http://dx.doi.org/10.1007/s0 0418-013-1174-x

Roloff AM, 2010. Homer 1a gates the induction mechanism for endocannabinoid-mediated synaptic plasticity. Journal of Neuroscience.(30): 3072-3081.
Saghatelian AM, 2006. A FAAH-regulated class of $\mathrm{N}$-acyl taurines that activates TRP ion channels. Biochemistry.(45): 9007-9015.

Sanchez-Blazquez P, Rodriguez-Munoz M, Vicente-Sanchez A, \& Garzon J, 2013. Cannabinoid receptors couple to nmda receptors to reduce the production of no and the mobilization of zinc induced by glutamate. Antioxid. Redox Signal.(19): 1766-1782.

Schlosburg J, Blankman J, Long J, Nomura D, Pan B, Kinsey S, 2010. Chronic monoacylglycerol lipase blockade causes functional antagonism of the endocannabinoid system. Nat. Neurosci.(13): 1113-1119.

Schmid HH, 1990. N-acylated glycerophospholipids and their derivatives. Progress in Lipid Research.(29): 1-43.

Shonesy BC, 2013. CaMKII regulates diacylglycerol lipase-alpha and striatal endocannabinoid signaling. Nature Neuroscience.(16): 456-463.

Simon GM, 2006. Endocannabinoid biosynthesis proceeding through glycerophospho- $\mathrm{N}$-acyl ethanolamine and a role for \{alpha\}/beta-hydrolase 4 in this pathway. The Journal of 
Biological Chemistry.(281): 26465-26472.

Simon GM, 2008. Anandamide biosynthesis catalyzed by the phosphodiesterase GDE1 and detection of glycerophospho-Nacyl ethanolamine precursors in mouse brain. The Journal of Biological Chemistry.(283):93419349.

Stella N, 2009. Endocannabinoid signaling in microglial cells. Neuropharmacology.(56): 244253.

Sugiura TKY, 2002. Biosynthesis and degradation of anandamide and 2-arachidonoylglycerol and their possible physiological significance. Prostaglandins Leukot Essent Fatty Acids.(66):173-192.

Sumislawski JJ, 2011. Reversible gating of endocannabinoid plasticity in the amygdala by chronic stress: A potential role for monoacylglycerol lipaseinhibition in the prevention of stressinduced behavioral adaptation. Neuropsychopharmacology.(36): 2750-2761.

Tam, Trembovler V, di Marzo V, Petrosino S, Leo G, Alexandrovich A, 2008. The cannabinoid CB1 receptor regulates bone formation by modulating adrenergic signaling. FASEB J.(22): 285-294.

Turu G, \& Hunyady L, 2010. Signal transduction of the CB1 cannabinoid receptor. Journal of Molecular Endocrinology.(44): 75-85.

Ueda NT, 2011. Biosynthesis and degradation of the endocannabinoid 2arachidonoylglycerol.

Biofactors.(37): 1-7.

Uyama TI, 2013. Involvement of phospholipase A/acyltransferase1 in $\mathrm{N}-$ acylphosphatidylethanolamine generation. Biochimica et Biophysica Acta.(1831): 16901701.

Van der Stelt MTM, 2005. Anandamide acts as an intracellular messenger amplifying Ca2+ influx via TRPV1 channels. EMBO J.(24): 30263037.

Van Sickle MD, 2005. Identification and functional characterization of brainstem cannabinoid CB2 receptors. Science.(310): 329-332.

Vellani VP, 2008. Functional lipidomics. Calcium-independent activation of endocannabinoid/endovanilloid lipid signalling in sensory neurons 
Jalur Sinyal dan Metabolisme Endocannabinoid: Tinjauan Pustaka

Hariyanto Raharjo, Loo; Agusaputra, Harman

by protein kinases $C$ and $A$ and thrombin. Neuropharmacology: 1274-1279.

Yang WD, 2010. Proteome scale characterization of human $\mathrm{S}$ acylated proteins in lipid raftenriched and non-raft membranes. Molecular \& Cellular Proteomics.(9): 54-70.

Zhao L, 2014. BDNF-endocannabinoid interactions at neocortical inhibitory synapses require

phospholipase C signaling. Journal of Neurophysiology.(111): 1008-1015.

Zou S, \& Kumar U, 2018. Cannabinoid Receptors and the Endocannabinoid System: Signaling and Function in the Central Nervous System. International Journal of Molecular Sciences: 1-23. 